\title{
NEUROHUMORAL CHANGES IN CHRONIC HEART FAILURE
}

\author{
Lenka Spinarova*, Jiri Vitovec
}

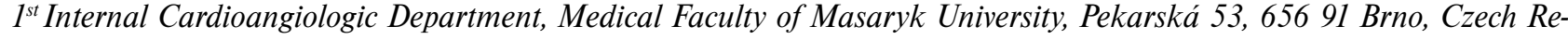 \\ public \\ *e-mail: lenka.spinarova@fnusa.cz
}

Received: September 10, 2007; Accepted: October 30, 2007

Key words: Heart failure/Humoral activation/Cytokines

Background: Humoral systems play an important role in the patophysiology and development of chronic heart failure (CHF).

Methods: We conducted a search of neurohumoral activation in heart failure and its risk in the development of CHF.

Results and conclusion: Neurohumoral factors may be divided into vasoconstrictive, vasodilative and cytokines. The main vasoconstrictive systems are the renin-angiotensin-aldosterone system (RAAS) and the sympathoadrenal system (SAS). Cytokines include tumour necrosis factor (TNF) alpha and interleukins. The systems of actions are interconnected and they mutually influence their secretion and activities. The possibilities of their detection and assessment for clinical purposes depend on their changes and kinetics in the organism and on the activity of individual metabolites. Apart from their vasoactive effects, the majority of humoral actions also interfere in the process of remodelling, function of the endothelium, blood elements, cardiomyocytes, cells of the smooth muscles, and in immunity as well as inflammatory processes. The rapid development of knowledge on the humoral actions in recent years has made possible their utilisation in diagnostics, treatment and prognosis.

Chronic heart failure $(\mathrm{CHF})$ is a term for a syndrome caused by disease of the heart muscle or by extracardiac influences which impair the work of the heart as a pump. Heart failure is defined as a defect in cardiac function when, despite sufficient filling of the chambers, cardiac output decreases and the heart is not able to maintain the metabolic needs of tissues, whilst activation of neurohumoral substances, apoptosis and adaptive changes of the myocardium at the molecular level develop.

Neurohumoral systems help to maintain circulatory homeostasis by increasing inotropy and chronotropy of the failing myocardium and by modulating vascular reaction. Vascular tension is thus regulated by mediators which either dilate or contract blood vessels in various parts of the organism in order to ensure blood flow through active organs (metabolic vasodilatation) while maintaining adequate perfusive pressure by vasoconstriction ${ }^{1}$.

According to their final effects, humoral substances may be divided into

a) vasoconstrictive

b) vasodilative

c) cytokines

Vasoconstrictive hormones have also antinatriuretic and antidiuretic effects, and they generally support cell proliferation. On the other hand the dilative substances are natriuretic and diuretic and they have antimitogenic effects. Despite activation of dilative mechanisms, systems leading to vasoconstriction and retention of fluids and salts are dominant ${ }^{2}$. (Table 1)

\section{A) VASOCONSTRICTIVE MECHANISMS}

\section{Sympathoadrenal system (SAS)}

Decrease in activity of mechanoreceptors in the carotic sinus and aortic arch, caused by a blood pressure drop, results in the release of catecholamines into the bloodstream: noradrenaline is released from nerve endings and adrenaline from adrenal glands. The positively chronotropic effect of the catecholamines increases heart rate and their positively inotropic effect increases the power and speed of myocardial contraction. Vasoconstriction of the systemic blood vessels, renal blood vessels and the splanchnic and skin veins caused by noradrenaline increases afterload and preload.

Table 1. Vasoconstrictive and vasodilative substances

\begin{tabular}{|l|l|}
\hline Vasoconstrictors & Vasodilators \\
\hline Adrenalin & Prostaglandin E2,I2 \\
Noradrenalin & Dopamine \\
Angiotenzin II & Natriuretic peptides (ANP, BNP) \\
Aldosterone & Endotel dependent relaxation. \\
Vazopresin & factor (EDRF) \\
Endothelin 1 & Adrenomedullin \\
(Big endothelin) & Kallikrein-kinin system \\
Prostaglandin F2 & Adenosine \\
Neuropeptide Y & Vasoactive intestinal peptide \\
Thromboxan A2 & Calcitonin gene- related peptide \\
\hline
\end{tabular}




\section{Renin-angiotensin-aldosterone system (RAAS)}

Renin is activated by a decrease in perfusive pressure and flow in the kidneys, a decrease in the concentration of sodium in the macula densa, intensive diuretic treatment and some vasodilatant drugs (hydralazine, prazosin, calcium antagonists), prostaglandins, increased sympathetic tonus and vasopressin. These influences increase the secretion of proteolytic renin enzyme from juxtaglomerular cells. Renin cleaves alphaglobulin angiotensinogen into decapeptide angiotensin I. After the clevage of two amino-acids by an angiotensin-converting enzyme (ACE), octapeptide angiotensin II (A II) is formed from decapeptide angiotensin $\mathrm{I}^{3}$.

As it is difficult to measure angiotensin II, measuring plasma renin activity (PRA) is used as the index of RAAS activity. PRA is increased in patients with manifest heart failure and it rises progressively during decompensation.

The effect of angiotensin II is direct peripheral vasoconstriction and further stimulation of the sympathetic system. It also stimulates the adrenal cortex to secrete aldosterone, stimulates the production of arginine vasopressin, causes hypertrophy of the myocardium and vascular wall (remodelling) and increases the volume of collagen in the myocardium and vascular wall. The effect of aldosterone is retention of sodium and excretion of potassium. In addition to an increased volume of circulating fluids, this results in greater vascular turgor, caused by the retention of water and sodium in the vascular wall. Aldosterone also activates fibroblasts in the myocardium to form collagen in greater amounts, in a way similar to A II. The RAAS is far more complex than originally supposed. Not only does it function as a circulatory endocrine system, but also as a local tissue system. The individual components are formed and are present in various tissues in which they also act. This characteristic is termed 'autocrine' or 'paracrine' and it complements the endocrine effect of the RAAS. The renin-angiotensin system as a whole participates in acute regulation of blood circulation, while tissue RAAS affects cardiovascular function and structure in the long term. Angiotesin II, released locally, is effective independently of the level of plasma renin activity ${ }^{4}$.

Angiotesin II operates particularly via receptor 1 which mediates effects such as vasoconstriction, hypertrophy of myocytes and vascular musculature, stimulation of sympathetic activity and oxygen radicals, and an increased level of inhibitor of plasminogen activator. By contrast, receptor 2 mediates antiproliferative effects and regulates cell differentiation and tissue repair. Stimulation of receptor 2 may influence the adverse effect on the remodelling mediated by receptor 1 . Besides angiotensin II, other end products are known whose clinical significance, however, has not been precisely determined as yet ${ }^{1}$.

\section{Arginine vasopressin (AVP)}

The secretion of arginine vasopressin is stimulated by higher osmolarity of blood. In heart failure, however, the release of vasopressin is increased by stimulating baroreceptors in the chambers via vagal afferent fibres and brain stem. In addition to vasoconstriction, vasopressin increases the effect of noradrenaline and angiotensin II: its main role is retention of water at the level of the distal tubule and the collecting tubules. Constriction of smooth muscle fibres is another effect of vasopressin. In heart failure, AVP may contribute to diluting hypoanatremia and thus to a poor patient prognosis. AVP acts through two types of receptors: vasoconstriction is effected via the V1 receptor, whereas resorption of water via the renal tubular (V2) receptor ${ }^{4}$.

\section{Endothelin}

Endothelin is an arterial and venous constrictor that is abundantly present in human tissues. Binding sites have been found in blood vessels, heart and kidneys. There are several types of peptides that are found in at least four isoforms (ET1, ET2, ET3 and a vasoactive intestinal contractor $)^{5}$.

The main cardiovascular endothelin is ET-1, ET-2 is produced mostly in the kidneys and the intestine, less in the myocardium, placenta and uterus, whilst ET-3 has been found in a greater concentration in the brain ${ }^{6}$.

Each kind of endothelin is a product of a separate gene which encodes the formation of a precursory protein - preproendothelin - which is further cleaved into proendothelin ('big endothelin') and still further, by the endothelin-converting enzyme (ECE), into the final product: endothelin. Similarly to RAAS, non-ECE ways of endothelin-1 formation also exist; these are likely to be similar to non-ACE ways. The formation of endothelin-1 is assisted by various factors, such as pressure and volume overload, epinephrine, angiotensin II, stress, hypoxia, endotoxin, cytokines, interleukins, thrombin and activated platelets.

On the other hand, the production of endothelin-1 is inhibited by endothel-dependent relaxation factor (EDRF), atrial natriuretic peptide (ANP) and prostaglandin I2 (PGI2) ( ref. $^{7}$ ).

Paracrine excretion of endothelin is predominant; it is released more to the adjacent cell than into the vascular lumen. Big endothelin, ET-1 and ET-3 are present in blood, but their concentration is low and represents around $25-30 \%$ of ET formed by endothelial cells. Of this quantity, the largest part is represented by big endothelin (65\%), endothelin-1 (25\%) and finally endothelin-3 (10\%).

The biological effects of endothelin are:

a) Cardiovascular: vasoconstriction, positively inotropic effect, reflexive bradycardia

b) Renal: an inrease in renal arterial resistance, a decrease in glomerular filtration, mesangial hypertrophy

c) Pulmonary: bronchoconstriction

d) Neuroendocrine: an increase in ANP, prostaglandins, renin, aldosterone, arginine-vasopressin

e) Growth: strong mitogen for smooth muscle cells, cardiocytes and fibroblasts

Endothelin is effective through receptor A (ET A) which is vasoconstrictive and causes hypertrophy and cell proliferation, whereas ET B has a vasodilatative effect. ET A receptor is found in smooth muscle cells and stimulation leads to constriction. Receptor ET B has a 
Table 2. Effects of Natriuretic Peptides

\begin{tabular}{|l|l|l|l|}
\hline \multicolumn{1}{|c|}{ KIDNEYS } & \multicolumn{1}{|c|}{ BLOOD VESSELS } & \multicolumn{1}{c|}{ HEART } & NEUROHUMORAL SYSTEM \\
\hline $\begin{array}{l}\text { Increase in GF } \\
\begin{array}{l}\text { Decrease in sodium } \\
\text { reabsorption }\end{array}\end{array}$ & $\begin{array}{l}\text { arteriodilatation } \\
\text { venodilatation } \\
\text { antiproliferation }\end{array}$ & $\begin{array}{l}\text { lusiotropic effect } \\
\text { antifibrotic effect } \\
\text { antiproliferation }\end{array}$ & $\begin{array}{l}\text { increase in vagal tone } \\
\text { decrease in sympathetic activity } \\
\text { decrease in renin activity } \\
\text { decrease in aldosterone excretion }\end{array}$ \\
\hline
\end{tabular}

dual activity: on the endothelial cell it leads to release of NO and prostaglandin $\mathrm{I} 2$ and thus to vasodilatation, while in the muscle cell it causes vasoconstriction, too ${ }^{6}$. Receptors A have roughly 10 times higher affinity for ET1 than ET-3, whereas receptors of the B type bind ET-1 and ET-3 with the same affinity. Systemic administration of endothelin results in short-term vasodilatation at first, which is caused by the release of vasodilatative substances PG12 and EDRF, and only after that long-term vasoconstriction occurs ${ }^{1}$.

Endothelin is also an important prognostic indicator of chronic heart failure and endothelin levels have been shown to correlate with degree of heart failure and also with degree of pulmonary hypertension ${ }^{8}$.

Big endothelin, which is the precursor of endothelin, may better reflect overproduction of this substance than the circulating endothelin itself which is rapidly cleaved and may not reach the pulmonary circulation. In some studies, big endothelin correlated better with haemodynamic parameters in right-heart catheterisation and echo parameters than endothelin ${ }^{9,10}$ and it also correlated better with the functional NYHA class and long-term prognosis of patients with chronic heart failure ${ }^{9}$.

\section{Neuropeptide Y (NPY)}

Neuropeptide Y was originally isolated from pig brain. Neuropeptide $Y$ is localised together with norepinephrine in sympathetic ganglia and fibres that innervate arterioles, veins and heart. It is a powerful vasoconstrictor, it also has vagolytic activity and it decreases cardiac contractibility ${ }^{11}$.

\section{Thromboxane A2 (TXA 2)}

Thromboxane A2 is produced in renal glomerules and causes aggregation of thrombocytes and vasoconstriction (including renal blood vessels) and thus it decreases renal flow and glomerular filtration. Its increase has been described in patients with severe heart failure NYHA IV as opposed to patients in NYHA I . Thromboxane A2 is excreted into urine as thromboxane B2 (TXB2), therefore its production is measured by means of TXB2 renal excretion $^{12}$.

\section{B) VASODILATIVE MECHANISMS}

Vasodilative mechanisms are activated in heart failure as well, but their overall effect is weakened by vasoconstriction and also by lower reactivity of the vascular wall which has a decreased elasticity due to increased content of nitrogen and water.

\section{Prostaglandins (E2, I2)}

Prostaglandins are produced in renal arterioles, glomerules and some parts of renal tubules. Production is increased in hypoperfusion of the kidneys together with A II, and their main role is the dilatation of the vas afferens, by which they increase the flow through glomerular blood vessels and support the sodium excretion ${ }^{4}$. Prostaglandins also directly inhibit the transport of sodium in cortical tubules and in medullary collecting tubules. The excretion of prostaglandins is influenced by production of angiotensin II, noradrenalin and arginine-vasopressin. On the other hand, prostaglandins support ANP excretion. In chronic heart failure, renal homeostasis is dependent on them.

\section{Dopamine}

Dopamine stimulates receptors D1 and D2 (dopaminergic), localised postsynaptically in renal, mesenteric, coronary and brain blood vessels. Activation of D1 receptors increases blood supply of the kidneys, activation of D2 receptors prevents further release of catecholamines into the synaptic fissure.

\section{Natriuretic peptides}

\section{Atrial natriuretic peptide}

Natriuretic peptide is secreted from the atria of the heart when the pressure in the right atrium increases in hypervolaemia. ANP is a C-residual peptide derived from the 126 aminoacidic pro-ANP precursor that is stored in secretory granules. The remainder of pro-ANP after cleavage of ANP proper is known as N-terminal ANP fragment (N-ANP). N-ANP is removed much more slowly and thus remains in the circulation in a much higher concentration than the actual ANP. The concentration of N-ANP is increased in NYHA I patients and in asymptomatic ventricular dysfunction and it has been a much more sensitive marker of the disorder than ANP itself ${ }^{13}$. The reason may be better detection of N-ANP, as it has a greater molecular 
stability and longer plasma half-life in comparison with ANP. The effects of ANP lie in relaxation of vascular vasoconstriction, a decrease in filling pressure, increased sodium secretion by the kidneys, inhibition of renin and aldosterone secretion and a decrease in vasopressin production.

\section{Brain natriuretic peptide (BNP)}

Brain natriuretic peptide was discovered in the pig brain - hence its name - but in humans it is almost exclusively excreted from the heart, especially from the ventricles $^{14}$. Its effects are similar to ANP, therefore these two peptides function as a dual cardiac natriuretic peptide system. (Table 2) Increased BNP levels are used to screen for heart failure ${ }^{15}$ and they correlate well with the severity of the left ventricle function ${ }^{16}$.

An increase in the level of ANP as well as BNP has also been documented in patients with severe heart failure and normal systolic function, which could point to the fact that the diastolic dysfunction itself is sufficient for the activation of natriuretic peptides ${ }^{17}$.

\section{Central nervous system natriuretic peptide (CNP)}

CNP is primarily present in the CNS rather than in the heart. It is effective above all in the brain where it acts vasodilatatively. In heart failure, its levels are not increased ${ }^{18}$.

For the binding of natriuretic peptides, there exist three forms of receptors that differ in affinity to individual peptides. Receptor A (NPR-A) has greater affinity for ANP and BNP, whereas NPR-B is more specific for CNP. The third receptor, NPR-C, serves more for the clearance of peptides ${ }^{16,19}$. Since it was discovered in the pig brain, CNP and its receptor NPR-B have been identified in various human tissues such as the central nervous system, renal tubular cells and vascular endothelial cells. The discovery of CNP in endothelial cells is of particular interest, as NPR-B is found in high concentrations in the adjacent smooth muscle cells. This leads to the hypothesis that CNP may be effective locally in the vascular wall ${ }^{18}$. The determination of CNP levels is limited by its very short biological half-life: 2.6 minutes. In heart failure, the plasma level of CNP shows no increase. However, increased production has been described in the tissue of myocardium. This could again support the fact that for pathological conditions, local tissue concentrations of CNP are more important. The in vitro effect of CNP is above all vasodilatative: more on the veins than on the arteries, it also inhibits smooth muscle cell proliferation.

\section{Natriuretic peptides as heart biomarkers}

For clinical practice, it has been proven that BNP and NT-proBNP levels are more accurate. They reflect disease severity and patient prognosis better than ANP. Determination of NT-proBNP levels is diagnostically more useful as it has longer biological half-life than the BNP level itself ${ }^{15,19}$.

Determination of the ANP level does not appear to have any advantage, as ANP is quickly released from the cytoplasm, and a very short biological half-life of 30$300 \mathrm{~s}$. BNP, on the other hand, is continuously released, shows a significant increase in de novo synthesis, a longer biological half-life and a better stability in the circulation than ANP, and it is produced by a greater mass of cardiomyocytes.

In acute as well as chronic heart failure, BNP secretion is increased. The levels of BNP and NT-proBNP may be determined from the plasma. In comparison with NTproBNP, BNP has a shorter half-life, is not dependent on age and is excreted by means of specific receptors. NTproBNP has a longer half-life, is dependent on age and is excreted by the kidneys ${ }^{20,21}$. There exists a high correlation between the levels of BNP and NT-proBNP, $r<0.93$.

On the basis of proven data, determination of BNP levels has become part of the algorithm used in the diagnostics of heart failure and has been included in the Guidelines of the European Society of Cardiology 22,23 .

\section{Heart failure}

The diagnostics of impaired function of the left ventricle, particularly in the early stages of heart failure and in patients with few symptoms, is difficult. BNP sensitivity is $90 \%$ and specificity $76 \%$. In a study of the BNP (Breathing Not Properly), 1,586 patients were examined for dyspnoea on emergency admission. The highest plasma concentrations of BNP were found in patients suffering from dyspnoea caused by heart failure, medium concentrations were found in patients with non-cardiac dyspnoea and a history of left ventricle dysfunction, and the lowest concentrations were found in patients without heart failure or left ventricle function disorder signs. Increased concentrations of BNP were found in NYHA III and IV classes as compared to NYHA I and II. The value of BNP, when lower than $100 \mathrm{pg} / \mathrm{ml}$, ruled out heart failure; values between 100 and $500 \mathrm{pg} / \mathrm{ml}$ did not exclude heart failure, and a value of over $500 \mathrm{pg} / \mathrm{ml}$ detected failure with $95 \%$ probability $^{24}$.

The values suggested as the norms for NT-proBNP levels are based on the PRIDE study ${ }^{25}$.

This study included patients from the PRIDE study in the USA, and also patients from Spain, New Zealand and the Netherlands. The objective was to determine standards of NT-proBNP values for a large international population of patients with dyspnoea. Prospective data from four centres on three continents were dealt with in the study.

1,256 patients suffering from dyspnoea were included in the study. Optimal limits for diagnosis and prognosis were sought through ROC analysis. 720 patients (57.3\%) had acute heart failure, $60 \%$ of these had newly developed acute heart failure and $40 \%$ had a decompensation of former heart failure. The median NT-proBNP levels in patients with acute heart failure was 5669 vs $177 \mathrm{pg} / \mathrm{ml}$, in those without, $(\mathrm{p}<0.001)$. NT-proBNP correlated with the severity of the symptoms, $(p<0.008)$.

Values under $300 \mathrm{pg} / \mathrm{ml}$ excluded acute heart failure, values from 300 to $1,800 \mathrm{pg} / \mathrm{ml}$ assessed acute heart failure as possible and values over $1,800 \mathrm{pg} / \mathrm{ml}$ confirmed 
acute heart failure. The threshold value of NT-proBNP level for acute heart failure, irrespective of age, was 300 $\mathrm{pg} / \mathrm{ml}$, with $98 \%$ negative predictive value.

With regard to age, the following values which identified acute heart failure were calculated: in patients under 50 of age $450 \mathrm{pg} / \mathrm{ml}$, in patients between 50 and 75 years of age $900 \mathrm{pg} / \mathrm{ml}$, and in those over 75 years of age 1,800 $\mathrm{pg} / \mathrm{ml}$ with a sensitivity of $92 \%$ and specificity of $84 \%$. The division according to sex meant no improvement either in sensitivity or specificity ${ }^{25}$.

When chronic heart failure is suspected, $125 \mathrm{pg} / \mathrm{ml}$ is considered to be the NT-proBNP level threshold value; this value is more than $450 \mathrm{pg} / \mathrm{ml}$ in patients over 75 years of age ${ }^{23,30}$.

Increased levels of NT-proBNP were the most prominent independent predictor of congestive heart failure, ( $p<0.00001)$, irrespective of renal function. The level of NT-proBNP was also the most prominent indicator of death within 60 days, $(\mathrm{p}<0.0006)$.

The FINN-AKVA study tried to determine which of the succession of NT-proBNP levels from admission to hospital to four weeks after discharge was the most important for patient prognosis. Lower values of the NTproBNP level were found in each period.in survivors than in those who died. A relative decrease in NT-proBNP level was more pronounced in survivors. The most significant change for six-month prognosis was a decrease in NTproBNP level between the first and second day by more than $50 \%$ (ref. $\left.^{26}\right)$.

In a similar way, the significance of short-term monitoring of NT-proBNP levels for patients' prognosis was the topic of Dr Bettencourt's work ${ }^{27}$.

182 patients, monitored for six months, were included in the study. The primary goal was rehospitalisation or death. 26 patients died in the hospital. The NT-proBNP levels median on admission was $6,778 \mathrm{pg} / \mathrm{ml}$ and on discharge it was $4,137 \mathrm{pg} / \mathrm{ml}, \mathrm{p}<0.001$. The patients were divided into three groups:

1. a decrease in the NT-proBNP level by at least $30 \%$, $\mathrm{n}=82$

2. no change in the level, $\mathrm{n}=49$

3. an increase in NT-proBNP level by at least $30 \%$, $\mathrm{n}=25$

The primary objective was achieved in $42.9 \%$ of patients. Parameters associated with the risk of death and/or rehospitalisation according to univariant analysis were as follows: length of hospitalisation, pulse rate, signs of volume overload, non-use of ACE inhibitors, NYHA class when admitted, level of NT-proBNP on admission and on discharge, and change in level of NT-proBNP. Independent parameters associated with risk of rehospitalisation or death were volume overload and change in the NT-proBNP level. These results show that both a change in the level of NT-proBNP during hospitalisation and NT-proBNP values before discharge were predictors of rehospitalisation or death from heart failure in patients in the six months following discharge ${ }^{27}$.

Thus, measuring NT-proBNP levels could help in deciding when to discharge the patient and whether the treatment for heart failure should be intensified ${ }^{17,19}$.

\section{Asymptomatic impairment of systolic function of the left ventricle}

The determination of plasma concentrations is less precise in this case since the patients' levels of NYHA I and II overlap ${ }^{15,16,25}$.

\section{Diastolic dysfunction}

The plasma concentration of BNP is increased in patients with diastolic failure, older patients with heart failure with preserved systolic function, hypertonic patients, aortic stenosis, and hypertrophic or restrictive cardiomyopathy. However, concentrations of BNP are higher in patients with systolic dysfunction than in those with isolated diastolic dysfunction and they are highest in patients with combined systolic and diastolic dysfunction. In patients with preserved systolic function, the level of BNP correlates with severity of diastolic dysfunction. It gradually increases in cases of impaired relaxation and it is the highest in patients with restrictive filling of the left ventricle ${ }^{16,28}$.

\section{Right heart failure}

The increase in levels of BNP in right ventricle disorders or in conditions that lead to the impairment of the right ventricle is not as straightforward as that in left heart failure, but the levels may be increased in pulmonary embolism. Higher levels of BNP have been found in patients with simultaneous left and right ventricle dysfunction than in patients with left ventricle dysfunction ${ }^{29}$.

\section{BNP as prognostic indicator}

Patients with heart failure and high plasma concentrations of BNP have higher cardiovascular and general mortality irrespective of age, functional NYHA classification, previous myocardial infarctions, ejection fraction, and maximum oxygen consumption. An increase in BNP is also a predictive factor of sudden death or necessity for heart transplantation ${ }^{19}$.

In patients with acute heart failure, BNP is an independent predictor of cardiovascular mortality, and it is also a prognostic indicator of subsequent clinical development in patients hospitalised with decompensated heart failure. Measuring of BNP levels before discharge may help to identify patients with a low risk of rehospitalisation in the course of the following month ${ }^{28}$.

Median of NT-proBNP levels was a predictor of mortality in major pharmacological studies of patients with heart failure (ANZ Heart Failure Study (NYHA II.-III) and COPERNICUS (NYHA IV)). The ValHeft study has the largest neurohormonal database of heart failure studies.

BNP and noradrenalin were determined in 4,300 patients out of 5,010. BNP was a statistically significant predictor of mortality.

The determination of BNP/NT-proBNP is one of the most useful indicators that may, when dynamically monitored, predict an unfavourable course of illness and determine the effect of heart failure treatment. It may be claimed that normal values of plasma concentration of 
BNP exclude heart failure and, vice versa, high levels of BNP confirm the diagnosis of heart failure ${ }^{17,20,21,24}$.

\section{Endothelium-dependent relaxation factor (EDRF)}

An intact endothelium produces a vasodilatative endothelium-dependent relaxation factor (EDRF), which is, chemically, nitrogen oxide originating in L-arginine. EDRF, as a nitrate, has a vasodilatative effect since it activates guanylate cyclase in the smooth muscle of blood vessels.

\section{Adrenomedullin}

Increased levels of adrenomedullin correlate with the symptomatology and haemodynamic severity of syndrome $^{49}$. Adrenomedullin acts as a vasodilatator in the systemic and pulmonary circulation induces vasodilatation in the kidneys, increases glomerular filtration, natriuresis and diuresis ${ }^{48}$. Adrenomedullin inhibits the excretion of aldosterone from the zona glomerulosa and the production of endothelin-1 (ref. $\left.{ }^{30}\right)$.

\section{Kallikrein-kinin system}

The distal tubules of the kidneys produce kallikreinprotease which affects kininogen and forms bradykinin and kallidin peptides. Both peptides cause vasodilation and natriuresis. Bradykinin also stimulates the formation of prostaglandins.

\section{Adenosine}

Adenosine is produced by myocytes and endothelial cells. It inhibits the release of catecholamines via receptor A1 and via receptor A2 it increases coronary flow and inhibition of platelets and leukocytes. It also inhibits the release of TNF alpha and renin. In patients with chronic heart failure, an increase in the level of adenosine has been described depending on the severity of the illness ${ }^{31}$.

\section{Vasoactive intestinal peptide (VIP)}

VIP is connected with the parasympathetic nervous system and it has a vasodilatative effect. It is structurally close to the hormones of the digestive tract - secretin and glucagon. In addition to vasodilatation, it also has a positive inotropic effect. It is present in heart nerves, particularly in the right atrium.

\section{Calcitonin gene-related peptide (CGRP)}

The CGRP is a powerful endogenous vasodilatator, localised together with the VIP in the parasympathetic nervous system.

When the function of the left ventricle is impaired, the above-mentioned neurohumoral mechanisms with a marked prominence of vasoconstriction and retention of sodium and water are activated. Preload and particularly afterload are excessively increased, which in turn further impairs the heart function. This closes the vicious circle. The plasma levels of noradrenaline, angiotensin II, atrial and ventricular natriuretic peptide, big endothelin and TNF directly determine the prognosis of patients with chronic heart failure.
Besides the above-mentioned haemodynamic consequences, neurohumoral stimuli also impair cardiac function by directly affecting the myocardium (hypertrophy, change in collagen synthesis). The changes of water and ionic economy mean an increased state of readiness for arrhythmias, mostly ventricular. The sick person dies either of progressing heart pump failure, or suddenly of malignant arrhythmia.

\section{C) CYTOKINES}

Cytokines are highly effective endogenous peptides of relatively low molecular weight with a number of biological effects, from influence on growth, leukocytic function, tissue, epithelial, endothelial and other cells that are involved in tissue repair and homeostasis, to specific effects on the pathophysiology of chronic heart failure ${ }^{32}$. The mechanism of effects is either through specific receptors, or through membranes. The most studied cytokines are: tumour necrosis alpha factor (TNF) and interleukin (IL) 6 and 1 ( ref. $\left.^{33}\right)$.

Cytokines are produced by immune system cells, the formation could be induced by a neurohormonal activation.

The origin of pro-inflammatory cytokines in heart failure is not entirely clear; there are three possible sources. The best-known sources are: 1) immune activation induced by endotoxins (in intestinal oedema), 2) myocardial formation of cytokines in haemodynamic overload, and 3 ) extra-myocardial production of cytokines ${ }^{34}$.

TNF alpha causes muscle loss, reduces muscular contractility and induces myocardial hypertrophy. Thus TNF causes endothelial dysfunction and at the same time impaired synthesis and increased skeletal muscle catabolism. An increase in TNF, which is observed especially in NYHA IV patients, may lead to a serious limitation of exercise capacity and correlates with cardiac cachexia and an adverse prognosis.

\section{Interleukin (IL) 1 and 6}

Interleukin 1 has a negatively inotropic effect owing to a decrease in cardiac contractility and stimulation of NO synthase ${ }^{35}$. It may induce apoptosis. Interleukin 6 is associated with a worse NYHA class, prolonged hospitalisation and a poor function of the left ventricle. Its role as a prognostic marker has not been clarified as yet and the mechanism of its harmful effect is not completely clear. There is, however, some scientific knowledge of its being involved in the development of ventricular hypertrophy through the stimulation of glycoprotein receptor 130 which is present on heart myocytes ${ }^{33}$.

\section{CONCLUSION}

Humoral actions are one of the cornerstones of the origin and development of heart failure. According to their basic characteristics, they may be divided into va- 
soconstrictive, vasodilatative and cytokines; in the first two, vasoconstrictive substances usually predominate. In addition to their vasoactive effects, some humoral actions are significantly involved in the process of remodelling and endothelial dysfunction. Their importance for clinical practice is now obvious: both for basic $\mathrm{CHF}$ diagnostics and for assessment of its progression and prognosis. The major systems are successfully blocked by treatment. Given the rapid development of knowledge in this field, further specification of the place of humoral substances in pathophysiology and CHF diagnostics, and perhaps in further therapeutic use of inhibition of their adverse effects, may be expected.

\section{ACKNOWLEDGEMENT}

Study was supported by research project MSM 0021622402.

\section{REFERENCES}

1. Štejfa M, a kol. Kardiologie (třetí, přepracované a doplněné vydání) Grada Publishing a. s. 2007, s 722

2. Widimský J. Srdeční selhání, 2. rozšířené a přepracované vydání, Triton 2003, s 556

3. Špinar J, Vítovec J. Chronické srdeční selhání, Medica s. r. o., Brno 2000, s 65

4. Špinarová L,Toman J. Humorální změny u chronického srdečního selhání. Cor et Vasa 2001:43(10):513-9

5. Yanagisawa M, Kurihana H, Kimura S, et al. A novel potent vasoconstrictor peptide produced by vascular endothelial cells. Nature 1988; 332:411-15

6. Bartůněk L. Endoteliny a chronická srdeční insuficience. Vnitřní Lékařství 2000; 46(1):54-57

7. Horký K. Patofyziologická úloha endotelinu u kardiovaskulárních onemocnění a možnost jeho blokády. Remedia 1998; 8(6):408416

8. Špinar J, Vítovec J, Špinarová L, Toman J, Kubecová L, Pacher $\mathrm{R}$, Stanek B, Wimmer A. The value of big endothelin level and hemodynamic variables in heart transplant candidates Cor et Vasa 2000; 42(10):495-500

9. Pacher R, Stanek B, Huelsman M, et al. Prognostic impact of big endothelin-1 plasma concentrations compared with invasive hemodynamic evaluation in severe heart failure. $\mathbf{J}$ Am Coll Cardiol 1996; 27(3):633-641

10. Špinarová L, Toman J, Pospíšilová J, et al. Humoral response in patients with chronic heart failure. Int J Cardiol 1998; 65:227-232

11. Zukowska-Grojec Z, Marks ES, Haass M. Neuropeptide Y is a potent vasoconstrictor and a cardiodepresssant in rat. Am J Physiol 1987; 253:H 1234

12. Castellani S, Paladini B, Paniccia R, et al. Increased renal formation of thromboxane A2 and prostaglandin F2 alpha in heart failure Am Heart J 1997; 133:94-100

13. Wijnbenga AAM, Balk AHM, Jonkman FAM et al. Relation of atrial natriuretic peptides to left ventricular systolic and diastolic function in heart failure. Eur J Heart Failure 1999; 1:51-58
14. Sudoh T, Kangawa K, Minamino $\mathrm{N}$ et al. A natriuretic peptide in porcine brain. Nature 1988; 332:78-81

15. Cowie MR, Struthers AD, Wood DA et al. Value of natriuretic peptides in assessment of patients with possible new heart failure in primary care. Lancet 1997; 350:1349-1353

16. Vítovec J, Špinarová L. Natriuretické peptidy-diagnostika a léčba. Remedia 2004;14(2):177-181

17. Oral I. Natriuretické peptidy - současný stav klinického využití jejich stanovení. Vnitřní Lék 2003; 49:521-523

18. Kalra PR, Anker SD, Struthers AD et al. The role of C - type natriuretic peptide in cardiovascular medicine. Eur Heart J 2001; 22:997-1007

19. Maisel AS, Krishnaswamy P et al. Rapid measurement of B-type natriuretic peptide in the emergency diagnosis heart failure. N Eng J Med 2002; 347:161-167

20. Špinar J, Vítovec J. Normy pro BNP a NT-pro BNP stanoveny. Cor et Vasa 2005;47(10):

21. Hradec J. Mohou se stát natriuretické paptidy křištálovou koulí kardiologa? JACC-CZ 2003; 5:255-257

22. Nieminen MS, Boehm M, Cowie MR et al. Executive summary of the guidelines on the diagnosis and treatment of acute heart failure. Eur Heart J 2005; 26:383-416

23. Swedberg K, Cleland J, Dargie H et al. Guidelines for the diagnosis and treatment of chronic heart failure. Eur Heart J 2005; 26:1115-1140

24. Maisel A, McCord J, Nowak RM et al. Results from Breathing Not Properly Study (BNP). J Am Coll Cardiol 2003; 41:2010-2017

25. Januzzi LJ, Camargo CA, Anwarudin S et al. The N-terminal pro-BNP investigation of dyspnea in the emergency department (PRIDE) study. J Am Coll Cardiol 2005; 95:948-954

26. Harjola VP, Siirla-Waris K, Peuhkurinen K et al: FINN-AKVA Finnish Acute Heart Failure study-Prognostic significance of NTproBNP as early follow-up. Abstract Book proCardio Symposium, $3^{\text {rd }}$ International Symposium on NT-proBNP,May 27-28,2005, Dresden, Germany

27. Bettencourt $\mathrm{P}$, Azevedo A, Pimenta $\mathrm{J}$ et al. N-terminal-pro-Brain Natriuretic Peptide predicts outcome after hospital discharge in heart failure patients. Circ 2004; 110:2168-2174

28. Staněk V. Kardiologie a biochemie. Znamenají natriuretické peptidy novou éru v diagnostice a kontrole léčby srdečního selhání. Cor Vasa 2002; 44:504-505

29. Špinarová L, Toman J, Meluzín J, Hude P, Krejčí J, Tomandl J, Vítovec J. Natriuretic peptides and myocardial function in chronic heart failure. Eur J Echocard 2003; 4:Suppl.1:S 34

30. Petrie MC, McClure SJ, Love MP, et al. Novel neuropeptide in the pathophysiology of heart failure; adrenomedullin and endothelin-1. Eur J Heart Failure 1999; 1:25-29

31. Funaya H, Kitakaze M, Node K, et al. Plasma adenosine levels increase in patients with chronic heart failure. Circulation 1997; 95:1363-1365

32. Pěnička M, Gregor P. Hypotéza kardiovaskulárních onemocnění. Postgraduální medicína 1999; 1:34-43

33. Niebauer $\mathbf{J}$. Inflammatory mediators in heart failure. Int $\mathbf{J}$ of Cardiology 2000; 72:209-213

34. Paulus WJ. How are cytokines activated in heart failure? Eur J Heart Fail 1999; 1:309-312

35. Francis SE, Holden H, Holt CM. et al. Interleukin-1 in myocardium and coronary arteries of patients with dilated cardiomyopathy. $\mathrm{J}$ Mol Cell Cardiol 1998; 30:215-230 